\title{
Rehabilited winter birds of Chimdi lake (Birju Tal) Sunsari, Nepal
}

\author{
K. Jha ${ }^{1}$ and B.R. Subba ${ }^{2}$ \\ ${ }^{1}$ Manmohan Memorial Polytechnic, Hattimuda, Sunsari, Nepal \\ ${ }^{1}$ Birat Campus, School of Science and Technology. Biratnagar, Morang, Nepal
}

\begin{abstract}
Chimdi lake (101.6 hect.) situated in Sunsari district is at its rehabilitating phase. Besides wetland birds several grass land, open land and garden birds also take shelter here. In the present survey altogether 60 species of bird were recorded in three months (October, November, December). Few birds like Common Shelduck, Purple Moorhen, Coot, Mallard, Eurasian Wigeon were seen to have rehabilitated whereas several species of bird such Pheasant-tailed Jacana, Ruddy Shelduck, Darter, Glossy Ibis, White Ibis, Opened Billed stork, White Necked stork, Sparrow Hawk, Dark Kite, Marsh Harrier, Golden Plover, Pheasant Tailed Jacana, Curlew, Little Egret which were recorded in the initial stage of the lake did not turn out this time. Except the population of Lesser Whistling Teal, the population other species of bird was not found increased well in spite of safe habitat and food availability.
\end{abstract}

Key words: Chimdi lake, Rehabilitation, winter birds

\section{Introduction}

Nepal attracts about 150 winter visitors which come mainly from Northern and Central Asia. These include Ducks, Waders, Birds of prey, Gulls, Terns, Thrushes, Warblers, Pipits, Wagtails, Finches, Storks and Buntings. Koshi Tappu which is one of the hot spot for bird in Nepal is only about $60 \mathrm{~km}$ west-north of Chimdi Lake.At initial stage of rehabilitation of the lake a detailed study of the lake was done for fifteen months (Surana et al., 2007). Heinen (1987) studied birds of Koshi Tappu and Koshi barage. Similar studies have been made (Subba 1995; Jha and Subb 2012; Limbu et al., 2012; Limbu et al.,2015). Now several vegetation and birds have rehabilitated naturally to some extent, plantation has also changed the physical feature of the lake.The lake has been one of the best hotspots for birds in eastern Nepal. meet the goal by conserving its beautiful fauna and flora. Local peoples have positive attitude about the conservation of important natural resource the lake is always necessary.

\section{Study area}

Chimdi lake or locally called Birju Tal is located at Chimdi Village Development Committee (VDC) ward no. 3 and 4 Sunsari district, Nepal. It is $12 \mathrm{~km}$ west of Biratnagar. It lies between $087^{\circ} 13^{\prime} 24.3^{\prime \prime}$ E longitude and $26^{\circ} 29^{\prime} 24.3$ " $\mathrm{N}$ latitude bearing a total area approximately 101.6 hectares. Vegetation Pistia, Echornia, Cyperus, Typha, Potamogeton, Ipomea, Mikenia macrantha, Ceratophyllum, Hydrilla, Valennaria, Colocasia. Lemna. Chara, Runnunculus aquatilis etc. are the vegetations observed in the lake area.Several herbs, shrubs and trees have been planted on dikes.

\section{Materials and Methods}

Direct observation method was applied to study the winter birds in the lake area. Observation was done weekly for three months (October, November, and December) on regular basis. Binoculars (7X50, 20X50) Digital cameras, GPS were used in the field. 


\section{Results and Discussion}

In the present survey, a total 60 species of birds belonging to 21 families were recorded (Table 1). In the list of rehabilitated birds come Purple Moorhen, Common shelduck, Coot, Mallard and Eurasian Wigeon which were not recorded (Surana et al., 2007). Many species of birds namely Darter, Glossy Ibis, White Ibis, Asian Openbill-Stork, White necked Stork, Lesser Adjutant, Sparrow Hawk, Dark kite, Marsh Harrier, Golden Plover, Pheasant Tailed Jacana, Curlew, Little Egret were recorded in October, November and December (Surana et al.,2007) did not turn out in this present survey. However, the population of Coot, Lesser Whistling teal, Indian Gallinule, Bronze-backed Jacana and several grassland birds has increased satisfactorily on one side but the population of Cattle Egret, Large Egret, Intermediate Egret, Ashy crowned Finch Lark, White-breasted King Fisher, Eurasian Kingfisher, Pied Kingfisher, Wagtails, Buntings has decreased remarkably rapidly in compared to the past record.

Rehabilitation of any species higher fauna is a time taking process. The rehabilitated bird species will gradually go on increasing provided proper management can have done. On the basis of types of habitat and food availability the lake will be inhabited by the birds. Unless habitats of wetland birds can be identified and established the habitats required, it is impossible to expect all wetland bird species to watch in the lake. It had been expected that rehabilitation of the birds would take place soon but because of climate change, the expected result could not be achieved, on one hand, population of every bird species has been decreasing every year, throughout the world on the other hand. Of course, there are some technical problems which seem to have been challenges in rehabilitation of the lake. Gradual improvement in the public awareness towards the importance of lake and lake diversity conservation sustainably is hopefully expected.

Table 1. Rehabilated winter birds of Chimdi lake.

\begin{tabular}{|c|c|c|c|}
\hline Sn & Common Name & Scientific Name & Family \\
\hline 1 & Little Grebe & Podiceps ruficolis & Prodicppedidae \\
\hline 2 & Little Cormorant & Phalacrocorax niger & \multirow{3}{*}{ Phalacrocoracidae } \\
\hline 3 & Great Cormorant & Phalacrocorax carbo & \\
\hline 4 & Cattle Egret & Bubulcus ibis & \\
\hline 5 & Indian Pond Heron & Ardeola grayii & \multirow{7}{*}{ Ardeidae } \\
\hline 6 & Intermediate Egret & Mesophoyx intermedia & \\
\hline 7 & Black-crowned Night Heron & Nycticorax nycticorax & \\
\hline 8 & Purple Heron & Ardea purpurae & \\
\hline 9 & Grey Heron & Ardea cinerae & \\
\hline 10 & Large Egret & Egretta alba & \\
\hline 11 & Little Eagret & Egretta garzetta & \\
\hline 12 & Black Ibis & Pseudibis papillosa & Threskiornithidae \\
\hline 13 & Lesser wistling- teal & Dendrocygna javanica & \multirow{8}{*}{ Anatidae } \\
\hline 14 & Common Shelduck & Tadorna tadorna & \\
\hline 15 & Garganey & Anas querquedula & \\
\hline 16 & Common Teal & Anas crecca & \\
\hline 17 & Mallard & Anas platyrhynchos & \\
\hline 18 & Eurasian wigeon & Anas penelope & \\
\hline 19 & Common pochard & Aythya ferina & \\
\hline 20 & Cotton teal & Nettapus coromandelianus & \\
\hline 21 & Indian Gallinule & Gallinula chloropus & \multirow{2}{*}{ Rallidae } \\
\hline 22 & Common moorhen & Gallinula chloropus & \\
\hline 23 & Purple moorhen & Porphyrio porphyrio & \multirow{4}{*}{ Charadriidae } \\
\hline 24 & Coot & Fulica atra & \\
\hline 25 & Red-wattled Lapwing & Vanellus indicus & \\
\hline 26 & Greater Painted-snipe & Rostratula benghalensis & \\
\hline
\end{tabular}




\begin{tabular}{|c|c|c|c|}
\hline 27 & Common Sandpiper & Tringa hypoleucos & Jacanidae \\
\hline 28 & Yellow Wattled Lapwing & Vanellus malaboricus & \multirow{4}{*}{ Columbidae } \\
\hline 29 & Bronze winged Jacana & Metopidius indicus & \\
\hline 30 & Spotted Dove & Streptopelia chinensis & \\
\hline 31 & Indian Ring Dove & Streptopelia decaoto & \\
\hline 32 & Red-Collared Dove & Streptopelia tranquebarica & \multirow[t]{2}{*}{ Cuculidae } \\
\hline 33 & Pigeon & Columba livia & \\
\hline 34 & Asian Koel & Eudynamys scolopacea & Centropodidae \\
\hline 35 & Indian Cuckoo & Cuculus micropterus & \multirow{2}{*}{ Alcedinidae } \\
\hline 36 & Great Coucal & Centropus sinensis & \\
\hline 37 & White- throated Kingfisher & Halcyon smyrnensis & Alaudidae \\
\hline 38 & Pied kingfisher & Ceryle rudis & Laniidae \\
\hline 39 & Rufous-winged Bushlark & Mirafra assamica & \multirow{4}{*}{ Corvidae } \\
\hline 40 & Brown Shrike & Lanius cristatus & \\
\hline 41 & House Crow & Corvus splendens & \\
\hline 42 & RufousTreepie & Dendrocitta vagabunda & \\
\hline 43 & Jungle Crow & Corvus macrorhynchos & \multirow{4}{*}{ Sturnidae } \\
\hline 44 & Black Drongo & Dicrurus macrocerus & \\
\hline 45 & Common Myna & Acridotheres tristis & \\
\hline 46 & Pied Myna & Sturnus contra & \\
\hline 47 & Bank Myna & Acridotheres ginginianus & \multirow[t]{2}{*}{ Pycnonotidae } \\
\hline 48 & Grey- headed Myna & Sturnus malabaricus & \\
\hline 49 & Red -vented Bulbul & Pycnonotus cafer & \multirow{3}{*}{ Sylviidae } \\
\hline 50 & Red- whiskered Bulbul & Pycnonotus jacosus & \\
\hline 51 & Dusky Warbler & Phylloscopus fuscatus & \\
\hline 52 & Common Tailor bird & Orthotomus suctorius & \multirow[t]{2}{*}{ Muscicapidae } \\
\hline 53 & Jungle Babbler & Turdoides striatus & \\
\hline 54 & Indian Robin & Saxicoloides fulicata & \multirow{4}{*}{ Passeridae } \\
\hline 55 & Black Redstart & Phoenicurus ochuros & \\
\hline 56 & Grey- headed Wagtail & Motacilla alba ducunensis & \\
\hline 57 & House Sparrow & Passer domesticus & \\
\hline 58 & Paddyfield Pipit & Anthus rufulus & \multirow[t]{3}{*}{ Psittacidae } \\
\hline 59 & Scaly-breasted Munia & Lonchura punctulata & \\
\hline 60 & Rose-ringed Parakeet & Psittacula krameri & \\
\hline
\end{tabular}

\section{Acknowledgement}

Authors would like to thank sincerely to the care taker organization of Chimdi lake for providing us with their data and information.

\section{Refrences}

Jha, K. \& B.R. Subba 2012. Impact of climate change on Birds of Biratngar and its surroundings. Nepalese Journal of Biosciences 2(2): 158-159

Limbu, K.P. \& B.R. Subba 2012. Avifaunal Status of Koshi Tappu Widlife reserve,Nepal after Koshi Flood Disaster 2008.1:213-225. In: Animal Diversity,Natural History and Conservation (Ed.) V.K. Gupta and A.K. Verma

Limbu, K.P., B.R. Subba \& R. Surana 2015. Population trend of Lesser Adjutant (Horsfield, 1829) (Ciconidae) in Eastern Nepal and protection efforts. Published by Hartmann and Weipert: Biodiversitat und Naturausstattung in Himalaya v-Erfurt.

Subba, B.R. 1995. Checklist of birds of Biratnagar, Newsletter for Birdwatchers 34(6):128-129.

Surana, R., B.R. Subba \& K.P. Limbu 2007. Avian diversity during rehabilitation stage of Chimdi Lake, Sunsari, Nepal. Our Nature 5: 75-80 